\title{
The evaluation of depression, anxiety and quality of life in children living with parental cancer: A case-control study
}

\author{
Ebeveyni kanser olan çocukların depresyon, anksiyete ve yaşam kalitesi \\ açısından değerlendirilmesi: Olgu kontrol çalışması \\ Ali Karayağmurlu1, Muhammet Emin Naldan², Oztun Temelli3, Murat Coskun4 \\ ${ }^{1}$ M.D., 4 Prof., Department of Child and Adolescent Psychiatry, Faculty of Medicine, Istanbul University, Istanbul, Turkey \\ https://orcid.org/0000-0001-5464-2891-https://orcid.org/0000-0002-4808-5870 \\ 2M.D., Department of Anesthesia, Regional Training and Research Hospital, Erzurum, Turkey https://orcid.org/0000-0002-7492-1975 \\ ${ }^{3}$ Assis. Prof., Department of Radiation Oncology, Faculty of Medicine, University of İnonu, Malatya, Turkey \\ https://orcid.org/0000-0003-3471-1284
}

\section{SUMMARY}

Objective: Parental cancers may have adverse effects on children and adolescents. The majority of studies on this subject have been performed in Western societies, and few have investigated quality of life in children. The purpose of this study was to investigate quality of life, anxiety and depressive symptoms in children living with parental cancer. Method: The case group consisted of 50 children, aged 8-16 years old, with a parent diagnosed with cancer. A group of 50 children, aged and gender matched, with healthy parents was included as the control group. All subjects were administered the Revised Child Anxiety and Depression Scale (RCAD-S) to assess the symptoms of anxiety and depression. Parents completed the Questionnaire for Quality of Life Assessment for Children and Adolescents: Parent Form to determine the child's quality of life. Results: Depression $(p=0.011)$ and anxiety $(p=0.011)$ scores were significantly higher in the case group than in the control group. Among the anxiety disorder symptoms, symptoms of separation anxiety were more common in case group $(p=0.032)$. Compared to the control group, the case group reported a significantly lower quality of life $(p=0.045)$. Discussion: Children of parents with cancer may suffer from anxiety and depression that may reduce their quality of life. Clinicians should collaborate with relevant disciplines and have a family-based, multidimensional view when evaluating patients with cancer who have children. Consulting or refering to child psychiatry may be considered when emotional and/or behavioral problems present in children.

Key Words: Parental cancer, offspring, quality of life, depression, anxiety

(Turkish J Clinical Psychiatry 2021;24:5-14)

DOI:10.5505/kpd.2020.87699

\section{ÖZET}

Amaç: Ebeveyn kanserleri çocuk ve ergenler üzerinde olumsuz etkilere neden olabilmektedir. Bu konuyla ilgili çalışmaların çoğunluğu batı toplumlarında yapılmış olup çocukların yaşam kalitesiyle ilgili çok az sayıda çalışma bulunmaktadır. Bu çalışmada ebeveyninde kanser tanısı olan çocuk ve ergenlerin yaşam kalitesi, kaygı ve depresyon belirtilerini değerlendirmek amaçlanmıştır. Yöntem: Çalışmanın olgu grubuna ebeveyninde kanser tanısı olan 8-16 yaş arasında 50 çocuk dahil edildi. Kontrol grubuna ise yaş ve cinsiyet açısından benzer özelliklere sahip ebeveyninde kanser tanısı olmayan 50 çocuk dahil edildi. Çalışmaya dahil edilen olguların ebeveynlerine anksiyete ve depresyon belirtileri için Çocuk Anksiyete ve Depresyon Ölçeği (ÇADÖ), yaşam kalitesi için Çocukların Yaşam Kalitesi Anketi-Revize Edilmiş (Kid-KINDL), sosyodemografik ve klinik özellikleri değerlendirmek için kişisel bilgi formu doldurtulmuştur. Bulgular: Olgu grubundaki katılımcıların depresyon $(p=0.011)$ ve anksiyete $(p=0.011)$ skorları kontrol grubundan anlamlı derecede yüksekti. Anksiyete belirtileri içerisinde özellikle ayrılık kaygısı belirtileri olgu grubunda kontrol grubundan anlamlı derecede daha yüksekti $(p=0.032)$. Olgu grubunun yaşam kalitesi skorları kontrol grubundan anlamlı derecede düşük bulunmuştur $(p=0.045)$. Sonuç: Kanser hastalarını tedavi eden klinisyenlerin ebeveyn kanserinin çocuklar üzerinde olumsuz ruhsal sonuçlara yol açabileceğini dikkate alması, kanserin psikosoyal sonuçlarının değerlendirmesi sırasında aile temelli, multidisiplinler bir yaklaşımı benimsemeleri faydalı olacaktır.

Anahtar Sözcükler: Ebeveyn kanseri, çocuklar, yaşam kalitesi, depresyon, kaygı 


\section{INTRODUCTION}

Cancer is one of the leading causes of death and is increasingly being recognized as a serious, worldwide public health problem. Surveys, such as one conducted by Torre, show that an estimated 18 million new cancer cases and 9.5 million cancer deaths occurred worldwide in 2018 (1). Cancer is not only a physical disease, but an ailment involving intense mental and psychosocial considerations. When someone is diagnosed with cancer, coping with this diagnosis is difficult for both the cancer patient and the patient's family. Parental cancer can be particularly challenging for children and adolescents $(2,3)$. Exposure to a parent's cancer may be traumatizing for children. The children of parents with cancer may experience many changes in their lives, like having to adjust daily routines, alter familial roles, experience educational difficulties, and encounter increased difficulty when regulating emotions and behaviors (4). The child's day-to-day routines may first be interrupted by frequent visits to the outpatient clinic, then by the unexpected hospitalization of the parent (5). Role changes may be observed within the familial system. The child of a parent diagnosed with cancer may consider the well-being of the parent to be a greater priority than the child's own (6). Children may also feel that the responsibilities of the parent diagnosed with cancer fall unto them, increasing the child's sense of personal responsibilities (7). This leads children and adolescents to engage in fewer social activities and to spend less time caring for oneself, and encourages increased rates of absence from school. In addition, children with a cancer-diagnosed parent experience impaired academic performance and have greater difficulty proceeding to higher education when compared to their peers (8-10). They may also experience behavioral and emotional problems in conjunction with the changes in their daily lives. Several internalizing and externalizing problems may be encountered in children with parental cancer, and numerous psychiatric disorders, such as anxiety disorders and depression, are seen in children at such times $(6,11-14)$.

There is a growing body of literature to support the claim that parental cancer negatively impacts a child's mental health $(12,15,16)$. In a systematic review, Walczak et al. have highlighted requiring further attention the effect of parental cancer on offspring (3). Although some research has analyzed the mental health of a patient with cancer, relatively few studies have investigated the impact of parental cancer on offspring (17). There have been only a few studies concerning this subject as it pertains to non-Western populations, and the majority of studies that have performed were qualitative; few quantitative studies implementing validated surveys have been performed $(3,18)$.

It is important to consider the quality of life for the children of parents diagnosed with cancer. Because, when a family is encountered with a lifethreatening parental disease, children in need of care may, unfortunately, be a "forgotten group". As mentioned above, they may experience changes and difficulties in their lives (19). This may lead to impairment in the quality of life of children (20). Quality of life is a multidimensional concept that involves all aspects of human functioning, concerning the physical, mental, emotional, and social domains. The quality of life for children of parents diagnosed with cancer is affected across several domains. However, there have been very few studies that consider the effects of a parent's cancer on the quality of a child's life $(3,21)$. This study addresses these research gaps by investigating whether parental cancer affects the mental health and the quality of life of a child with a parent diagnosed with cancer. Additionally, factors affecting the quality of life have investigated by focusing on anxiety and depression in children with a cancerdiagnosed parent.

This research addresses the following inquiries:

Are the symptoms of anxiety and depression more commonly seen in the children living with parental cancer than in the control group?

Is there any differences between children with parental cancer and control group in quality of life?

Is there any correlation relationship between quality of life and anxiety depression symptoms in the children living with parental cancer? 
Which factors are associated with impairment of quality of life and the presence of anxiety / depression?

\section{METHODS}

\section{Sample}

This study was performed between July 2017 and January 2018 at the İnönü University Medical Faculty Radiation Oncology Clinic in Turkey. The case group consisted of children ages 8-16, with one parent diagnosed with cancer anywhere from three months to five years prior to the study; the parent was required to possess sufficient command of the Turkish language so forms could be completed. There were no criteria for exclusion in terms of the type or stage of the parent's cancer. Parents who declined participation and parents suffering from a psychotic disorder or an intellectual disability were not surveyed. Patients admitted to the İnönü University Radiation Oncology Department or presented to the outpatient clinic who met the study's criteria were contacted with preliminary information about the study. Consent was obtained or denied, and those patients who provided consent have been included in this study. The control group was comprised of children with similar ages and genders to the case group, but with parents not diagnosed with cancer or any other chronic disease. To obtain subjects for the control group, healthy parents admitted to the İnönü University Medical Faculty Hospital for routine health checks were contacted and informed of this study. Parents agreeing to participate have been included in this study. During the selection of subjects, care was taken to ensure that there was no history of any chronic disease capable of affecting the quality of life of the child, to avoid factors that could potentially complicate the study's findings.

\section{Procedure}

Informed consent forms were obtained from parents who met the inclusion criteria and agreed to take part in the study. The Personal Information Form, the Revised Child Anxiety and Depression Scale (RCAD-S), and the Questionnaire for Quality of Life Assessment for Children and
Adolescents Parent Form (Kid-KINDL) were completed by the parents. In the case group, the scales were completed by parents diagnosed with cancer, while in the control group they were also completed by healthy parents.

\section{Measures}

Personal Information Form: Parents in both groups were asked to complete personal information forms. Forms in the case group were completed by the healthy parents. These forms collected information concerning the parent's gender and education, the age and gender of the child, and data concerning the health status of the affected parent (i.e., when the cancer was diagnosed, the diagnosis itself, and the parent's surgical history).

Revised Child Anxiety and Depression Scale (RCAD$S$ ): The RCAD-S was developed by Chorpita et al (22). The validity and reliability of the scale for Turkey were studied by Görmez et al (23). The Turkish version of the scale was used in this study. The Cronbach a coefficient of the Turkish RCAD$\mathrm{S}$ was 0.95 . Cronbach alpha coefficients for the RACD-S subscales demonstrated satisfactory internal consistency. These were $a=0.79$ for Separation Anxiety Disorder (SAD), $a=0.86$ for Social Phobia (SoF), $a=0.76$ for Obsessive Compulsive Disorder (OCD), $a=0.85$ for Panic Disorder, $a=0.85$ for Generalized Anxiety Disorder (GAD), and $a=0.84$ for Major Depressive Disorder (MDD). Similarly, the Cronbach a coefficients of the original RCAD-S subscales ranged from 0.73 to $082(\mathrm{SAD}=0.76$, $\mathrm{SoP}=0.82, \mathrm{OCD}=0.73, \mathrm{PD}=0.85, \mathrm{GAD}=0.77$, and MDD $=0.76$ ). The scale consists of 47 items. Parents scored items using a 4-point Likert-type scale $(0=$ never, $1=$ sometimes, $2=$ frequently, and $3=$ always). The scale covers depression and anxiety disorders (SAD, PD, GAD, and SoP), and the scores for depression and anxiety can be tallied once the form has been completed. RCAD-S provides both categorical and dimensional data regarding these disorders.

Questionnaire for Quality of Life Assessment for Children and Adolescents Parent Form (KidKINDL): "Kid-KINDL" was developed by Ravens- 
Sieberer et al. to evaluate the health-related quality of life for children (24). The reliability and validity of the form for Turkey have been studied by Eser et al. in 2008 (25). The original form of Kid-KINDL features a Cronbach coefficient of 0.95, whereas the Turkish version of the Kid-KINDL has a coefficient of 0.78; the Turkish coefficient was used for this study. Kid-KINDL consists of a 5-point Likerttype scale $(1=$ never, $2=$ rarely, $3=$ sometimes, 4 $=$ often, and $5=$ always). The scale contains 24 items in six sections investigating the quality of life in the domains of physical well-being, emotional well-being, self-esteem, family, friends, and school functioning. Scores were calculated for each section and converted into a value between 0 and 100 . Scores are positively oriented, with higher scores indicating a higher quality of life. The general qua lity of life score and the scores for each section were considered during statistical analysis.

\section{Data Analysis}

Statistical analysis was performed on SPSS Windows 21.0 software. Data were expressed as percentages, arithmetic means, and standard deviations. Data distribution was assessed using the Kolmogorov-Smirnov test. An independent sample t-test was used for normally distributed data and a Pearson correlation analysis used for correlations, while the Mann-Whitney U test was used for data that was abnormally distributed. Qualitative variables were compared using the chi-square test. In the data analyses, corrections for multiple testing were not used. Probability $(\mathrm{p})$ values $<0.05$ were regarded as statistically significant (two-tailed test).

\section{Ethical Considerations}

In accordance with the Declaration of Helsinki, approval for the study was obtained from the Ethics Committee of the Erzurum Regional Training and Research Hospital on 21.06.2017 (no. 37732058514/10).

Table 1. Descriptive characteristics of the Case and Control Groups

\begin{tabular}{|c|c|c|c|}
\hline Variable & Case group $(\mathrm{n}=50)$ & Control group $(\mathbf{n}=50)$ & P-value \\
\hline Age (years) & $11.38-2.53$ & $10.64-1.88$ & $0.109^{\mathrm{a}}$ \\
\hline Gender & & & $0.688^{\mathrm{b}}$ \\
\hline Female & $22(44 \%)$ & $24(48 \%)$ & \\
\hline Male & $28(56 \%)$ & $26(52 \%)$ & \\
\hline Paternal Education (years) & $9.04-4.43$ & $8.96-4.62$ & $0.926^{\mathrm{a}}$ \\
\hline Maternal Education (years) & $7.58-4.94$ & $7.28-5.03$ & $0.920^{\mathrm{a}}$ \\
\hline Family income status & & & $0.488^{\mathrm{b}}$ \\
\hline Minimum wage or less & $39(78 \%)$ & $36(72 \%)$ & \\
\hline Above the minimum wage & $11(22 \%)$ & $14(28 \%)$ & \\
\hline \multicolumn{4}{|l|}{ Time since diagnosis } \\
\hline$>1$ year & $25(55.6 \%)$ & - & \\
\hline ? 1 year & $20(44.4 \%)$ & - & \\
\hline \multicolumn{4}{|l|}{ Type of parental cancer } \\
\hline $\begin{array}{l}\text { Breast } \\
\text { Head and Neck } \\
\text { Gastrointestinal } \\
\text { Other }\end{array}$ & $\begin{array}{l}25(50 \%) \\
9(18 \%) \\
6(12 \%) \\
10(20 \%) \\
\end{array}$ & $\begin{array}{l}- \\
- \\
- \\
-\end{array}$ & \\
\hline \multicolumn{4}{|l|}{ History of Surgery } \\
\hline Yes & $43(86 \%)$ & - & \\
\hline No & $7(14 \%)$ & - & \\
\hline \multicolumn{4}{|l|}{ Gender of Parents } \\
\hline Female & $11(22.4 \%)$ & - & \\
\hline Male & $38(77.6)$ & - & \\
\hline
\end{tabular}

Notes: ${ }^{a}$ Mann Whitney U-test. ${ }^{b} x^{2}$ test,${ }^{c}$ Independent sample t-test. 
The evaluation of depression, anxiety and quality of life in children living with parental cancer: A case-control study

Table 2. The Kid-KINDL scores of the case and control groups

\begin{tabular}{lcll}
\hline & Case group $(\mathbf{n}=\mathbf{4 9})^{\#}$ & ${\text { Control group }(\mathbf{n = 5 0})^{\#}}^{\#}$ & P-value \\
\hline Kid-KINDL-PW & $70.28-22.84$ & $76.37-12.51$ & $0.235^{\mathrm{a}}$ \\
\hline Kid-KINDL-EW & $69.64-21.30$ & $82.25-11.80$ & $\mathbf{0 . 0 0 2}^{\mathrm{a}}$ \\
\hline Kid-KINDL-SE & $75.25-30.45$ & $78.25-14.89$ & $0.225^{\mathrm{a}}$ \\
\hline Kid-KINDL-Fa & $77.16-17.19$ & $80.75-20.74$ & $0.216^{\mathrm{a}}$ \\
\hline Kid-KINDL-Fr & $75.12-21.40$ & $71.87-17.13$ & $0.129^{\mathrm{a}}$ \\
\hline Kid-KINDL-Sc & $52.93-21.19$ & $63.25-14.15$ & $\mathbf{0 . 0 3 8}^{\mathrm{a}}$ \\
\hline Kid-KINDL-T & $70.49-13.52$ & $75.10-8.35$ & $\mathbf{0 . 0 4 5}^{\mathrm{b}}$ \\
\hline
\end{tabular}

Notes: ${ }^{a}$ Mann Whitney U-test. ${ }^{b}$ Independent t-test. ${ }^{\#}$ Data presented as mean - SD. Bold data, P<0.05(significance).

Abbreviation: PW, Physical well-being; EW, Emotional well-being; SE, Self-esteem; Fa, Family; Fr, Friends; Sc, School

functioning; Kid-KINDL-T, Total Kid-KINDL scores.

\section{RESULTS}

One hundred children were included in the study. Fifty children with one parent diagnosed with cancer constituted the case group, made up of 28 $(56 \%)$ boys and $22(44 \%)$ girls. Ages ranged from 8 to 16 years old, with a mean of $11.52 \pm 2.7$ years. The control group consisted of $26(52 \%)$ boys and $24(48 \%)$ girls, with a mean age of $10.64 \pm 1.88$ years. The two groups were similar in age, gender, education, and the education status of the parent $(p>0.05)$. Table 1 details the characteristics of the two groups.

Statistical testing revealed significant differences in the scores for quality of life between the two groups $(p<0.05)$. Among the quality of life domains, emotional well-being domain in particular significantly affected a child's quality of life (z-score $=-3.068, \mathrm{p}$ $=0.002$ ). The subscale scores of the case group and the control group are summarized in Table 2.

Children in the case group indicated significantly higher anxiety ( $\mathrm{t}$-score $=2.214, \mathrm{p}=0.029)$ and depression scores $(\mathrm{z}$-score $=-2.531, \mathrm{p}=0.011)$ than those of the control group. Among anxiety disorder symptoms, the most prominent symptoms suggest separation anxiety disorder $(\mathrm{z}$-score $=-2.142, \mathrm{p}=$
0.032). The two groups' RCAD-S scores are summarized in Table 3 .

High RCAD-S scores indicate a high incidence of psychiatric symptoms, while high Kid-KINDL scores indicate a high quality of life. A correlation analysis of the findings reveals a moderate-strong inverse correlation between RCAD-S and KidKINDL-T scores $(\mathrm{p}<0.001$, correlation coefficient $=-0.611)$. A significant inverse correlation was observed that concerns a decreased quality of life and the symptoms of anxiety and depression. Figure 1 shows a correlation scatter plot for total RCAD-S scores and total Kid-KINDL scores.

The next concern was determining which factors are associated with the anxiety, depression, and quality of life of children with cancer diagnosed in one parent. In terms of gender, anxiety symptoms were significantly higher in girls than in boys ( $t$ score $=2.105, \mathrm{p}=0.041)$. Parental characteristics investigated included gender, income status, whether the patient had undergone surgery, and the duration of the parent's cancer. Depression scores were significantly higher in children whose mothers had been diagnosed with cancer compared to the scores for children whose fathers had been diagnosed with cancer $(\mathrm{z}$-score $=-2.217, \mathrm{p}=0.027)$, while their quality of life scores were significantly

Table 3. The RCAD-S scores of the case and control groups

\begin{tabular}{llll}
\hline & ${\text { Case group }(\mathbf{n = 5 0})^{\#}}$ & ${\text { Control group }(\mathbf{n}=\mathbf{4 9})^{\#}}$ & P-value \\
\hline RCAD- SAD & $6.30-4.72$ & $4.10-2.42$ & $\mathbf{0 . 0 3 2}^{\mathrm{a}}$ \\
\hline RCAD- GAD & $4.38-2.88$ & $3.76-2.81$ & $0.222^{\mathrm{a}}$ \\
\hline RCAD- PD & $3.16-3.74$ & $1.94-1.37$ & $0.411^{\mathrm{a}}$ \\
\hline RCAD- SoP & $7.38-4.85$ & $5.70-3.12$ & $0.100^{\mathrm{a}}$ \\
\hline RCAD- OCD & $3.79-3.18$ & $3.34-3.16$ & $0.471^{\mathrm{a}}$ \\
\hline RCAD-Ta & $25.04-14.64$ & $19.20-11.39$ & $\mathbf{0 . 0 2 9}^{\mathrm{b}}$ \\
\hline RCAD- MDD & $5.97-5.28$ & $3.28-2.92$ & $\mathbf{0 . 0 1 1}^{\mathrm{a}}$ \\
\hline RCAD-Ts & $31.02-18.91$ & $22.46-13.58$ & $\mathbf{0 . 0 1 1}^{\mathrm{b}}$
\end{tabular}

Notes: ${ }^{a}$ Mann Whitney U-test. ${ }^{b}$ Independent sample t-test. ${ }^{\#}$ Data presented as mean - SD. Bold data, $\mathrm{P}<0.05$ (significance). Abbreviation: MDD, ,Major Depressive Disorder; GAD, Generalized Anxiety Disorder; SAD, Separation Anxiety Disorder; PD, Panic Disorder; SoP, Social Phobia; OCD, Obsessive Compulsive Disorder; Ta, Total Anxiety; RCAD-Ts, Total RCAD-S Scores. 


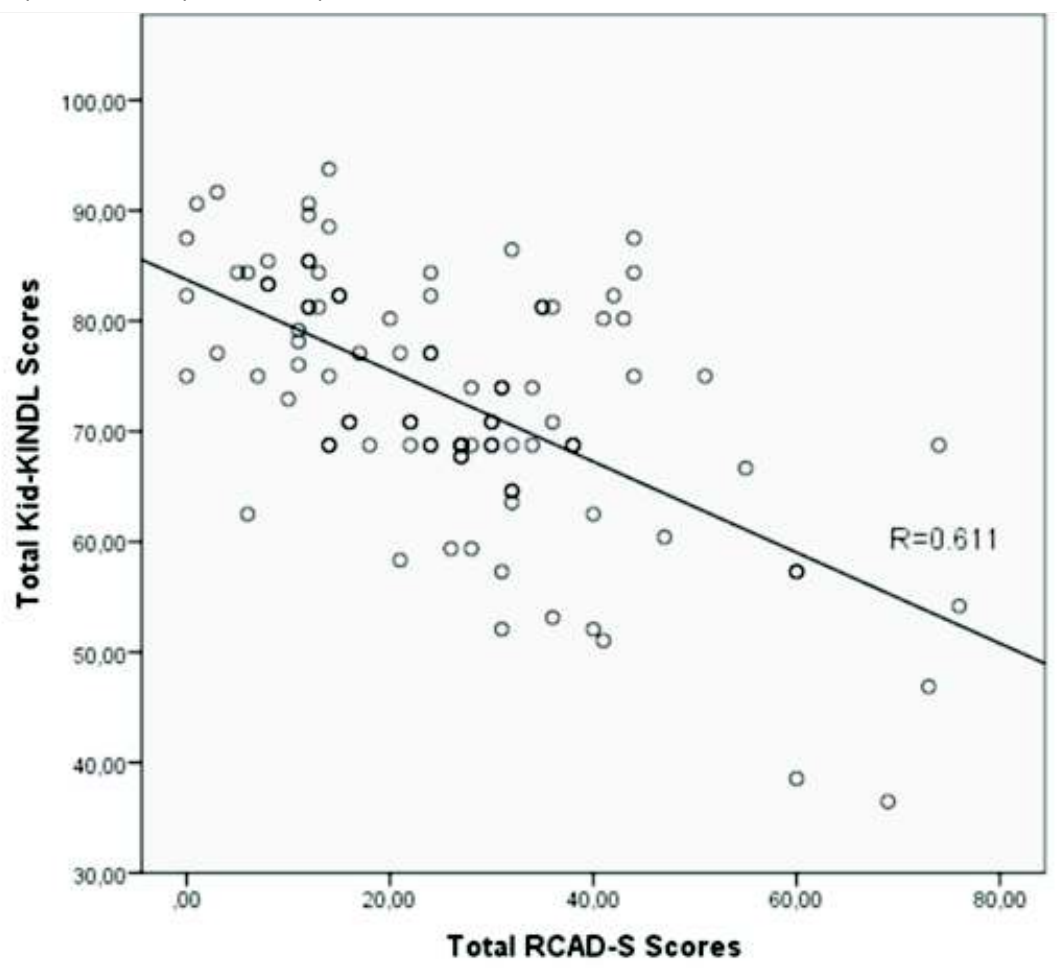

Figure 1. The correlation scatter plot for total Revised Child Anxiety and Depression Scale (RCAD-S) scores and total Questionnaire for Quality of Life Assessment for Children and Adolescents Parent Form (Kid-KINDL) scores in the case group

lower ( $\mathrm{z}$-score $=-2.064, \mathrm{p}=0.039)$. A subject's wage, whether it was below, at, or above minimum wage, did not significantly relate to the scores of anxiety, depression, or quality of life. A child's quality of life decreased significantly if a parent had undergone surgery compared to cases in which a parent had no history of surgery ( $z$-score $=-2.310, p=0.019)$. No significant difference was determined in anxiety, depression or quality of life scores between the children of parents diagnosed with cancer more than one year previously and those of parents diagnosed less than one year before. The variables possibly related to anxiety, depression, and quality of life are summarized in Table 4.

\section{DISCUSSION}

This study examines the relationship between a parent's cancer and the child's levels of anxiety and depression and the child's quality of life. Anxiety scores were significantly higher in the case group than in the control group. These results are consistent with previous studies. Costas-Muniz determined a high level of anxiety in $44 \%$ of adolescents with parents with cancer (26). Flahault et al. also reported high scores of anxiety in the offspring of cancer patients (27). Most studies in the field have focused solely on the prevalence of anxiety symptoms. Few studies have investigated the types of anxiety disorders implied by these symptoms. Total anxiety scores were considerably high in the case group for this study, with symptoms particularly indicating the prominence of separation anxiety disorder (3). This is to be expected, because separation anxiety disorder is defined as a clinical condition characterized by extreme anxiety and fear of separation from individuals to whom the individual has developed attachment (generally the mother and father) (28).

The most significant difference between the psychiatric disorders of the control group and the case group was the considerable presence of depression symptoms indicated by the case group. These findings are consistent with other research. Küçükoğlu et al. reported that depressive symptoms were particularly high in children of parents with cancer (17). Rainville et al. determined higher psychological distress and depressive states in children of parents with cancer when compared against the normal population $(16,28)$. A pronounced inverse correlation was observed between the total score for 
The evaluation of depression, anxiety and quality of life in children living with parental cancer: A case-control study

Table 4. Comparison of mean anxiety, depression and quality of life scores in terms of the descriptive characteristics of the children in the case group

\begin{tabular}{|c|c|c|c|}
\hline & $\begin{array}{l}\text { RCAD-S Anxiety } \\
\text { score }^{\#}\end{array}$ & RCAD-S Depression score ${ }^{\#}$ & Total Kid-KINDL scores ${ }^{\#}$ \\
\hline \multicolumn{4}{|l|}{ Gender of Children } \\
\hline Male $(n=28)$ & $21.35-10.88$ & $5.00-4.02$ & $69.40-13.48$ \\
\hline Female $(n=21)$ & $29.95-17.61$ & $7.28-6.47$ & $71.82-13.76$ \\
\hline P-value & $0.041^{\mathrm{a}}$ & $0.164^{\mathrm{a}}$ & $0.539^{\mathrm{a}}$ \\
\hline \multicolumn{4}{|l|}{ Gender of Parents } \\
\hline Paternal Cancer $(\mathrm{n}=11)$ & $19.36-13.49$ & $3.09-3.26$ & $76.04-15.90$ \\
\hline Maternal Cancer $(n=38)$ & $26.68-14.71$ & $6.81-5.48$ & $68.88-12.53$ \\
\hline P-value & $0.113^{\mathrm{b}}$ & $0.027^{\mathrm{b}}$ & $0.039^{b}$ \\
\hline \multicolumn{4}{|l|}{ Family income } \\
\hline Minimum wage or less $(n=39)$ & $25.10-14.46$ & $6.00-5.40$ & $69.84-13.64$ \\
\hline Above the minimum wage $(\mathrm{n}=10)$ & $24.80-16.12$ & $5.90-5.04$ & $72.72-13.48$ \\
\hline P-value & $0.954^{\mathrm{a}}$ & $0.958^{\mathrm{a}}$ & $0.539^{\mathrm{a}}$ \\
\hline \multicolumn{4}{|l|}{ History of Surgery } \\
\hline Yes $(n=42)$ & $25.45-15.07$ & $6.21-5.32$ & $68.92-13.72$ \\
\hline No $(n=6)$ & $21.66-13.27$ & $4.66-5.65$ & $81.77-6.06$ \\
\hline P-value & $0.563^{\mathrm{a}}$ & $0.512^{\mathrm{a}}$ & $0.019^{b}$ \\
\hline \multicolumn{4}{|l|}{ Time since diagnosis } \\
\hline$<1$ year $(\mathrm{n}=20)$ & $20.80-12.61$ & $4.75-4.52$ & $70.88-15.36$ \\
\hline$? 1$ year $(n=24)$ & $28.79-16.51$ & $6.58-5.82$ & $70.20-12.95$ \\
\hline P-value & $0.083^{\mathrm{a}}$ & $0.258^{\mathrm{a}}$ & $0.874^{\mathrm{a}}$ \\
\hline
\end{tabular}

the quality of life and the scores of anxiety and depression. Quality of life declined as anxiety and depression scores increased. Children with a parent diagnosed with cancer are frequently observed internalizing problems. However, there have been few studies that examine the quality of life for these children. Research seems to indicate that there have been no studies that simultaneously investigate both the quality of life and the scores of anxiety and depression in children with a parent diagnosed with cancer $(21,29)$. However, it was noted that the correlation could not exhibit a casual relationship between the variables as bidirectional relation is quite possible by reason of the cross-sectional design of the present study.

Quality of life was determined to be significantly lower in children exposed to a parent's cancer diagnosis than the quality of life reported by the control group. This trend was particularly evident in the domains of emotional well-being and school functioning. These findings are consistent with those of Hauken et al. who found that children living with parental cancer were lower quality of life than the control group (29). In contrast to Hauken, Bultmann et al. determined a higher quality of life in children with parental cancer than in the normal population (30). Although several studies have reported that children exposed to parental cancer internalize various problems, the quality of life of these children has not been determined to be adversely affected; as mentioned above, there have been few studies concerning a child's quality of life. Götze et al. also emphasize the need for new studies on this subject $(3,21,29)$.

A parent's history of surgery and the gender of the child were also associated with a child's quality of life and that child's anxiety score, respectively. Additionally, there is a significant relationship between the parent's gender and the child's quality of life and depression scores. In this study, girls' anxiety scores were significantly higher than boys' scores. These results are compatible with the findings of the majority of studies $(6,14,31)$. Girls have been more affected than boys in the majority of studies (32-34). Qualitative research indicates that daughters are inclined to feel responsible for filling 
a maternal role (7). In this study, children with mothers with cancer had significantly higher depression scores than those with fathers with cancer. Due to the fact that the majority of the studies are conducted in mothers with breast cancer, few studies have investigated the effect of the gender of the affected parent, and the results of those studies have not been consistent. Two studies have reported that maternal illness had adverse effects on children $(30,35)$. A number of other studies have found no significant effects of parental gender $(36,37)$. No significant relationship was detected between the duration of parental cancer and a child's anxiety, depression, or quality of life. Published studies present inconsistent findings regarding the effect of the duration of a parent's illness on a child's behavior (37-41). In accordance with this study's findings, a number of other studies have found that there was no relationship between the duration of a di-sease and the internalization and externalization of a child's problems (37-39). However, a longitudinal study conducted by Forehand et al. indicated that familial stressors, including parental diseases, contribute to the behavioral problems of children in a six-year follow-up period (40). Similarly, a meta-analysis on behavioral problems of children with chronically ill parents showed that there is a significant relationship between the longer duration of a parent's illness and the behavioral problems of a child (41). It was determined that children with parents with a history of surgery reported significantly lower quality of life scores than those with parents without a history of surgery. The results of this study are consistent with the findings of a study that investigated the psychosocial effects of parent transplant surgery on children. In this qualitative study, the majority of children surveyed expressed similar feelings of uncertainty and anxiety (especially separation anxiety), a disrupted family life, a desire for normality, and the importance of social support (42).

\section{Study limitations}

There are a number of limitations to this study. The first is the relatively small sample size and the fact that it was performed in a single center. Second, the study has a cross-sectional design. Third, the lack of sufficient information concerning the stages of parental cancer, non-surgical interventions, and the fact that the diagnoses of cancer were not homogeneous made it difficult to assess the effects of the severity of a parent's cancer on a child. In addition to these concerns, the anxiety and depression symptoms were evaluated by using only one clinical assessment scale and the symptoms in children were not confirmed by a child and adolescent psychiatrist.

\section{Clinical implications}

Anxiety symptoms are frequently seen in children with parental cancer, although, as discussed above, there has been little research to determine the most common anxiety disorders. It is important for the management of anxiety symptoms seen in these children to determine this. It will be particularly useful for clinicians to make an early diagnosis to treat separation anxiety in children with parental cancer, and to consult the relevant departments. Similarly, determining which domains of quality of life are affected will be beneficial for early intervention. This study indicates the impairment of the academic and emotional well-being domains in particular.

\section{CONCLUSION}

In addition to being a physical disease, cancer has important psychosocial effects $(43,44)$. The results of this investigation show that the symptoms of depression and anxiety in children with a parent diagnosed with cancer increased significantly when compared to peers, while children's quality of life decreased significantly. Another important aspect of this study is the assessment of the anxiety symptoms observed to determine the child's disorder more accurately, and the domains most significantly impaired concerning a child's quality of life. Separation anxiety symptoms were noticeably more common among the anxiety disorder symptoms reported by the children in this study. The quality of life pertaining to the domains of school and emotional well-being was significantly lower in children exposed to a parent's cancer diagnosis compared to those children whose parents were not diagnosed with cancer. 


\section{Conflicts of interest}

The authors declare that they have no conflict of interest.

\section{Acknowledgments}

We would like to thank the patients and their families who agreed to participate in our study.

\section{REFERENCES}

1. Global Cancer Observatory. All cancers Source: Globocan 2018. Available at: http://gco.iarc.fr/today/data/factsheets/cancers/39-All-cancers-fact-sheet.pdf. Accessed October 2, 2018.

2. Palmer S, Patterson P, Thompson K. A national approach to improving adolescent and young adult (AYA) oncology psychosocial care: the development of AYA-specific psychosocial assessment and care tools. Palliat Support Care 2014; 12:183188.

3. Walczak A, McDonald F, Patterson P, Dobinson K, Allison K. How does parental cancer affect adolescent and young adult offspring? A systematic review of recent literature. Int J Nurs Stud 2017; 77:54-80.

4. Shah BK, Armaly J, Swieter E. Impact of Parental Cancer on Children. Anticancer Res 2017; 37:4025-4028.

5. Buchbinder M, Longhofer J, McCue K. Family routines and rituals when a parent has cancer. Fam Syst Health 2009; 27:213.

6. Morris JN, Martini A, Preen D. The well-being of children impacted by a parent with cancer: an integrative review. Support Care Cancer 2016; 24:3235-3251.

7. Stiffler D, Haase J, Hosei B, Barada B. Parenting experiences with adolescent daughters when mothers have breast cancer Oncol Nurs Forum 2008; 35:113-120.

8. Johnson LS. Developmental strategies for counseling the child whose parent or sibling has cancer. J Couns Dev 1997; 75:417-427.

9. Cass B, Smith C, Hill T, Blaxland M, Hamilton M. Young carers in Australia: understanding the advantages and disadvantages of their care giving. 2009.

10. Stamatopoulos V. One million and counting: the hidden army of young carers in Canada. J Youth Stud 2015; 18:809-822.

11. Huizinga GA, Visser A, van der Graaf WT, Hoekstra HJ, Klip EC, Pras E, Hoekstra-Weebers JE. Stress response symptoms in adolescent and young adult children of parents diagnosed with cancer. Eur J Cancer 2005; 41:288-295.

12. Visser A, Huizinga GA, van der Graaf WT, Hoekstra HJ, Hoekstra-Weebers JE. The impact of parental cancer on children and the family: a review of the literature. Cancer Treat Rev 2004; 30:683-694.

13. Huizinga GA. The impact of parental cancer on children. University Library Groningen][Host], 2006

14. Osborn T. The psychosocial impact of parental cancer on children and adolescents: a systematic review. Psychooncology
Correspondence address: M.D., Ali Karayagmurlu, Department of Child and Adolescent Psychiatry, Faculty of Medicine, Istanbul University, Istanbul, Turkey dralikarayagmurlu@gmail.com
2007; 16:101-126.

15. Metcalf CA, Arch JJ, Greer JA. Anxiety and its correlates among young adults with a history of parental cancer. $\mathrm{J}$ Psychosoc Oncol 2017; 35:597-613.

16. Rainville F, Dumont S, Simard S, Savard MH. Psychological distress among adolescents living with a parent with advanced cancer. J Psychosoc Oncol 2012; 30:519-534.

17. Küçükoğlu S, Çelebioğlu A. Identification of psychological symptoms and associated factors in adolescents who have a parent with cancer in Turkey. Eur J Oncol Nurs 2013; 17:75-80.

18. Kallander EK, Weimand BM, Becker S, Van Roy B, Hanssen-Bauer K, Stavnes K, Faugli A, Kufås E, Ruud T. Children with ill parents: extent and nature of caring activities. Scand J Caring Sci 2018; 32:793-804.

19. Niemelä M, Hakko H, Räsänen S. A systematic narrative review of the studies on structured child-centred interventions for families with a parent with cancer. Psychooncology 2010; 19:451-461.

20. Kühne F, Krattenmacher T, Bergelt C, Ernst JC, Flechtner HH, Führer D, Herzog W, Klitzing KV, Romer G, Möller B. Parental palliative cancer: psychosocial adjustment and healthrelated quality of life in adolescents participating in a German family counselling service. BMC Palliat Care 2012; 11:21-29.

21. Götze H, Ernst J, Brähler E, Romer G, von Klitzing K. Predictors of quality of life of cancer patients, their children, and partners. Psychooncology 2015;24(7):787-795.

22. Chorpita BF, Yim L, Moffitt C, Umemoto LA, Francis SE. Assessment of symptoms of DSM-IV anxiety and depression in children: A revised child anxiety and depression scale. Behav Res Ther 2000; 38:835-855.

23. Gormez V, Kilincaslan A, Ebesutani C, Orengul AC, Kaya I, Ceri V, Nasiroglu S, Filiz M, Chorpita BF. Psychometric properties of the parent version of the Revised Child Anxiety and Depression Scale in a clinical sample of Turkish children and adolescents. Child Psychiatry Hum Dev 2017;48(6):922-933.

24. Ravens-Sieberer U, Bullinger M. Assessing health-related quality of life in chronically ill children with the German KINDL: first psychometric and content analytical results. Qual Life Res 1998; 7:399-407.

25. Eser E, Yüksel H, Baydur H, Erhart M, Saatli G, Cengiz Ozyurt B, Ozcan C, Ravens-Sieberer U. The Psychometric Properties of the New Turkish Generic Health-Related Quality of Life Questionnaire for Children (Kid-KINDL). Turk 
Psikiyatri Derg 2008; 19.

26. Costas-Muñiz R. Hispanic adolescents coping with parental cancer. Support Care Cancer 2012; 20:413-417.

27. Flahault C, Sultan S. On being a child of an ill parent. Rorschachiana 2010; 31:43-69.

28. Naldan ME, Karayagmurlu A, Ahıskalıglu EO, Cevizci MN, Aydin P, Kara D. Is surgery a risk factor for separation anxiety in children?. Pediatr Surg Inter 2018; 34:763-767.

29. Hauken MA, Senneseth M, Dyregrov A, Dyregrov K. Anxiety and the Quality of Life of Children Living With Parental Cancer. Cancer Nurs 2018;41:E19-E27.

30. Bultmann JC, Beierlein V, Romer G, Möller B, Koch U, Bergelt C. Parental cancer: Health-related quality of life and current psychosocial support needs of cancer survivors and their children. Int J Cancer. 2014; 135:2668-2677.

31. Korneluk YG, Lee CM. Children's adjustment to parental physical illness. Clin Child Fam Psychol Rev 1998;1:179-193.

32. Phillips F. The experience of adolescents who have a parent with advanced cancer: A phenomenological inquiry. Palliat Support Care 2015; 13:1057-1069.

33. Nicholls W, Patterson P, McDonald FE, Hulbert-Williams NJ. Unmet needs in young adults with a parent with a chronic condition: a mixed-method investigation and measure development study. Scand J Caring Sci 2017; 31:191-200.

34. Grabiak BR, Bender CM, Puskar KR. The impact of parental cancer on the adolescent: an analysis of the literature. Psychooncology 2007; 16:127-137.

35. Compas BE, Worsham NL, Epping-Jordan JE, Grant KE, Mireault G, Howell DC, Malcarne VL. When mom or dad has cancer: markers of psychological distress in cancer patients, spouses, and children. Health Psychol 1994; 13:507-515.

36. Lindqvist B, Schmitt F, Santalahti P, Romer G, Piha J. Factors associated with the mental health of adolescents when a parent has cancer. Scand J Psychol 2007; 48:345-351.

37. Visser A, Huizinga GA, Hoekstra HJ, van der Graaf WT, Hoekstra-Weebers JE. Temperament as a predictor of internalising and externalising problems in adolescent children of parents diagnosed with cancer. Support Care Cancer 2007; 15:395403.

38. Huizinga GA, Visser A, Van der Graaf WT, Hoekstra HJ, Stewart RE, Hoekstra-Weebers JE. Family-oriented multilevel study on the psychological functioning of adolescent children having a mother with cancer. Psychooncology 2011; 20:730-737.
39. Gazendam-Donofrio S, Hoekstra H, Van Der Graaf W, van de Wiel HB, Visser A, Huizinga GA, Hoekstra-Weebers JE. Family functioning and adolescents' emotional and behavioral problems: when a parent has cancer. Ann Oncol. 2007; 18:19511956.

40. Forehand R, Biggar H, Kotchick BA. Cumulative risk across family stressors: Short- and long-term effects for adolescents. J Abnorm Child Psychol 1998; 26:119-128.

41. Sieh DS, Meijer AM, Oort FJ, Visser-Meily JM, Van der Leij DA. Problem Behavior in Children of Chronically Ill Parents: A Meta-Analysis. Clin Child Fam Psychol Rev 2010; 13:384-397.

42. Fulbrook P, Leisfield T, Wiggins K. Children's conceptions of their parent's lung transplant. J Child Health Care 2013; 17:616.

43. Bikmazer A, Orengul AC, Buyukdeniz A, Okur FV, Gokdemir Y, Perdahli Fis N. Coping and psychopathology in children with malignancy and bronchiectasis. Pediatr Pulmonol 2020; 55:214-220.

44. Yurduşen S, Akyüz C, Gençöz F. The importance of mothers' self cohesion when their children diagnosed were with cancer. Klin Psikiyatr Derg 2020; 23:214-228. 